Phytopharmacovigilance

\section{Challenges for phytopharmacovigilance}

\section{E Ernst}

\section{It is important that the safety of herbal medicines is scientifically addressed}

$\mathrm{T}$ hroughout history, plants have been used for medicinal purposes and, during the last three decades, we have witnessed a most remarkable revival of herbal medicine. ${ }^{1}$ Germany is the country with the largest per head consumption of herbal medicines. In 2002, the 100 best selling products achieved a total turnover of 420 million Euros. ${ }^{2}$ This high level of popularity means, among other things, that we ought to ensure that no harm is done. Even though the media frequently try to persuade us otherwise, not all herbal medicines are free of adverse effects (table 1)..$^{2-5}$ Phytopharmacovigilancethat is, the systematic research of the safety of herbal medicines-has therefore become an important topic. In this article, I will briefly outline some of the challenges encountered in this area.

Herbal medicines are usually not patentable. Therefore, keen commercial impetus for systematic research rarely exists. Consequently there is a lack of hard data on herbal safety. ${ }^{3}$ Much of the available evidence is either built on nonclinical investigations ${ }^{4}$ or on incomplete and thus inconclusive clinical data. ${ }^{5}$ Depending on the circumstances, both under-reporting ${ }^{6}$ and over-reporting ${ }^{7}$ of herbal adverse effects have been susof the press in this area is a well recognised aggravating factor. ${ }^{8}$ Users of herbal medicines often do not inform their doctor, and conventional healthcare professionals sometimes lack sufficient knowledge of herbal medicine to advise their patients responsibly. As a consequence, the evidence regarding the nature and incidence of adverse effects caused by herbal medicines is woefully incomplete.

In most countries, herbal medicines are not regulated as medicines but marketed as dietary supplements. The quality of some products has repeatedly been shown to be suboptimal,' some of the most extreme examples include Asian herbal mixtures which can be contaminated (for example with heavy metals, micro-organisms, pesticides) or drugs. ${ }^{10}$ Even top quality herbal medicines suffer from a degree of product pected, and the unduly strong influence adulterated with powerful prescription

Table 1 Examples of popular herbal medicines ${ }^{*}$ and associated risks

\begin{tabular}{|c|c|c|c|c|}
\hline Common name & Latin name & Indication & Adverse effects & Potential interactions with \\
\hline Garlic & Allium sativum & $\begin{array}{l}\text { Raised blood } \\
\text { cholesterol }\end{array}$ & $\begin{array}{l}\text { Allergic reactions, } \\
\text { nausea, heartburn }\end{array}$ & $\begin{array}{l}\text { Anticoagulants, } \\
\text { antidiabetics }\end{array}$ \\
\hline Hawthorn & Crataegus spp & Heart failure & $\begin{array}{l}\text { Nausea, dizziness, } \\
\text { fatigue }\end{array}$ & $\begin{array}{l}\text { Cardiac glycosides, } \\
\text { antihypertensives, nitrates }\end{array}$ \\
\hline Horse chestnut & $\begin{array}{l}\text { Aesculus } \\
\text { hippocastanum }\end{array}$ & Varicose veins & $\begin{array}{l}\text { Pruritus, nausea, } \\
\text { gastrointestinal } \\
\text { symptoms }\end{array}$ & Anticoagulants \\
\hline Kava & $\begin{array}{l}\text { Piper } \\
\text { methysticum } \\
\text { Forster }\end{array}$ & Anxiety & Liver damage & Drugs acting on CNS \\
\hline $\begin{array}{l}\text { Maidenhair } \\
\text { tree }\end{array}$ & Ginkgo biloba & $\begin{array}{l}\text { Dementia, } \\
\text { peripheral } \\
\text { vascular } \\
\text { disease }\end{array}$ & $\begin{array}{l}\text { Gastrointestinal } \\
\text { symptoms, diarrhoea, } \\
\text { vomiting, allergic } \\
\text { reactions }\end{array}$ & Anticoagulants \\
\hline Saw palmetto & $\begin{array}{l}\text { Serenoa repens } \\
\text { Bartram }\end{array}$ & $\begin{array}{l}\text { Benign prostate } \\
\text { hyperplasia }\end{array}$ & $\begin{array}{l}\text { Gastrointestinal } \\
\text { complaints, dysuria, } \\
\text { decreased libido }\end{array}$ & Hormonal drugs \\
\hline St John's wort & $\begin{array}{l}\text { Hypericum } \\
\text { perforatum }\end{array}$ & $\begin{array}{l}\text { Mild/moderate } \\
\text { depression }\end{array}$ & $\begin{array}{l}\text { Gastrointestinal } \\
\text { symptoms, allergic } \\
\text { reactions, fatigue }\end{array}$ & $\begin{array}{l}\text { All drugs metabolised by } \\
\text { cytochrome P450 enzyme } \\
\text { system }\end{array}$ \\
\hline
\end{tabular}

${ }^{*}$ All examples are of well documented efficacy (data extracted from Ernst et a ${ }^{\beta}$ ).

variability. This may not be altogether avoidable, considering that the raw material for herbal medicines obviously varies according to factors such as climate, soil, and season, method of harvesting, drying, storing, or extraction. Product quality will thus always be a considerable challenge to phytopharmacovigilance.

Product identification can be a further obstacle. Many commercially available products contain multiple ingredients. For instance, Sinupret (Bionorica, Germany), the best selling herbal medicinal product in Germany (total sales in 2002 were 22.6 million Euros), contains five different medicinal plants. ${ }^{2}$ Asian herbal mixtures typically contain about twice that amount. In such cases, it is often impossible to discover which ingredient caused a reported health problem. Brand names and sometimes even plant nomenclature suffer from a babylonian confusion. ${ }^{9}$ One herbal extract can be contained in dozens of different brands, and not infrequently identical brand names contain different mixtures of plants. Labelling of commercial products is often less than sufficient. Associations between one herbal ingredient and a reported adverse effect can therefore be difficult, sometimes impossible to establish.

Consumers of herbal medicines tend to be affluent, middle aged, and chronically ill. ${ }^{1}$ They are thus likely to combine herbal medicines with prescriptive drugs. Herb-drug interactions have thus become an important subject. ${ }^{359}$ The list of herbal medicines with potential for such interactions seems endless. ${ }^{11}$ Yet only relatively few clinical cases of herb-drug interactions have been documented in the medical literature. ${ }^{12}$ It is unclear whether this indicates that, in clinical practice, interactions occur only rarely or whether it suggests that not looking for such events means not recognising them.

In conclusion, phytopharmacovigilance is a new area of scientific inquiry. Because of the current popularity of herbal medicines, it has become important for public health. Phytopharmacovigilance faces numerous challenges. In the interest of the consumer we should address them with scientific rigour.

Postgrad Med J 2004;80:249-250. doi: 10.1136/pgmi.2004.021527

Correspondence to: Dr E Ernst, Complementary Medicine, Peninsula Medical School,

Universities of Exeter and Plymouth, 25 Victoria Park Road, Exeter EX2 4NT, UK; Edzard. Ernst@pms.ac.uk

\section{REFERENCES}

1 Eisenberg D, David RB, Ettner SL, et al. Trends in alternative medicine use in the United States; 1990-1997. JAMA 1998;280:1569-75. 
2 Schulz V, Hänsel R. Rational phytotherapie. A physician's guide to herbal medicine. 5th Ed. Berlin: Springer-Verlag, 2003.

3 Ernst E, Pittler MH, Stevinson C, et al. The desktop guide to complementary and alternative medicine. Edinburgh: Mosby, 2001.

4 Hänsel R, Keller K, Rimpler H, et al. Hager's Handbuch der Pharmazeutischen Praxis. Berlin Springer-Verlag, 1994.

5 Ernst E. Risks associated with complementary therapies. In: Dukes MNG, Aronson JK, eds.
Meyler's side effects of drugs. 14th Ed. Amsterdam: Elsevier, 2000:1649-81.

6 Barnes J, Mills SY, Abbot NC et al. Different standards for reporting ADRs to herbal remedies and conventional OTC medicines face-to-face interviews with 515 users of herbal remedies. Br J Clin Pharmacol 1998:45:496-500.

7 Schulze J, Raasch W, Siegers C-P. Toxicity of kava pyrones, drug safety and precautions $-a$ case study. Phytomed 2003;10:68-73.

8 House of Lords Select Committee on Science and Technology. Complementary and alternative medicine. Sixth report. Session 1999-2000 (HL123). London: Stationery Office, 2000.

9 De Smet PAGM. Herbal remedies. N Engl J Med 2002;347:2046-56

10 Ernst E. Toxic heavy metals and undeclared drugs in Asian herbal medicines. Trends Pharmacol Sci 2002:23:136-9.

11 Ernst E. Herb-drug interactions-an update. Perfusion 2003; 16:175-94.

12 Fugh-Berman A, Ernst E. Herb-drug interactions: review and assessment of report reliability. Br J Clin Pharmacol 2001;52:587-95.

\section{Clinical Evidence-Call for contributors}

Clinical Evidence is a regularly updated evidence based journal available worldwide both as a paper version and on the internet. Clinical Evidence needs to recruit a number of new contributors. Contributors are health care professionals or epidemiologists with experience in evidence based medicine and the ability to write in a concise and structured way.

\section{Currently, we are interested in finding contributors with an interest in} the following clinical areas:

Altitude sickness; Autism; Basal cell carcinoma; Breast feeding; Carbon monoxide poisoning; Cervical cancer; Cystic fibrosis; Ectopic pregnancy; Grief/bereavement; Halitosis; Hodgkins disease; Infectious mononucleosis (glandular fever); Kidney stones; Malignant melanoma (metastatic); Mesothelioma; Myeloma; Ovarian cyst; Pancreatitis (acute); Pancreatitis (chronic); Polymyalgia rheumatica; Post-partum haemorrhage; Pulmonary embolism; Recurrent miscarriage; Repetitive strain injury; Scoliosis; Seasonal affective disorder; Squint; Systemic lupus erythematosus; Testicular cancer; Varicocele; Viral meningitis; Vitiligo However, we are always looking for others, so do not let this list discourage you.

\section{Being a contributor involves:}

- Appraising the results of literature searches (performed by our Information Specialists) to identify high quality evidence for inclusion in the journal.

- Writing to a highly structured template (about 2000-3000 words), using evidence from selected studies, within 6-8 weeks of receiving the literature search results.

- Working with Clinical Evidence Editors to ensure that the text meets rigorous epidemiological and style standards.

- Updating the text every eight months to incorporate new evidence.

- Expanding the topic to include new questions once every 12-18 months.

If you would like to become a contributor for Clinical Evidence or require more information about what this involves please send your contact details and a copy of your CV, clearly stating the clinical area you are interested in, to Claire Folkes (cfolkes@bmigroup.com).

\section{Call for peer reviewers}

Clinical Evidence also needs to recruit a number of new peer reviewers specifically with an interest in the clinical areas stated above, and also others related to general practice. Peer reviewers are health care professionals or epidemiologists with experience in evidence based medicine. As a peer reviewer you would be asked for your views on the clinical relevance, validity, and accessibility of specific topics within the journal, and their usefulness to the intended audience (international generalists and health care professionals, possibly with limited statistical knowledge). Topics are usually 2000-3000 words in length and we would ask you to review between 2-5 topics per year. The peer review process takes place throughout the year, and our turnaround time for each review is ideally 10-14 days.

If you are interested in becoming a peer reviewer for Clinical Evidence, please complete the peer review questionnaire at www.clinicalevidence.com or contact Claire Folkes(cfolkes@bmigroup.com). 